\title{
In vitro evaluation of transdermal nicotine delivery systems commercially available in Brazil
}

\author{
André Luís Morais Ruela, Eduardo Costa Figueiredo, Aline Gravinez Perissinato, Ana Carolina \\ Zogbi Lima, Magali Benjamim Araújo, Gislaine Ribeiro Pereira*
}

Department of Pharmacy, Faculty of Pharmaceutical Sciences, Federal University of Alfenas, Alfenas, MG, Brazil

\begin{abstract}
The aim of this study was to develop and validate a method for evaluating the release and skin permeation from transdermal nicotine patches using the vertical diffusion cell (VDC). The VDC is an experimental apparatus employed in research, development, and the pharmaceutical field because it can simulate conditions closest to those established in clinical trials. Two transdermal nicotine delivery systems marketed in Brazil to release $14 \mathrm{mg}$ over 24 hours were evaluated. Release studies were carried out using a regenerated cellulose dialysis membrane and permeation studies were carried out using excised porcine ear skin. The results indicated that nicotine release from both evaluated patches follows Higuchi's release kinetics, while skin permeation studies indicated zero-order release kinetics. Nicotine release rates were different between both evaluated patches, but drug permeation rates were not significantly different. According to validation studies, the method was appropriate for evaluating in vitro performance of nicotine patches. The proposed method can be applied to in vitro comparative studies between different commercial nicotine patches and may be used as an auxiliary tool in the design of new transdermal nicotine delivery systems.
\end{abstract}

Uniterms: Nicotine/release and skin permeation. Transdermal delivery patches/evaluation. Vertical diffusion cell. Skin permeation. Transdermal formulations/ nicotine delivery systems.

O objetivo deste trabalho foi o desenvolvimento e a validação de metodologia empregando a célula de difusão vertical para avaliação da liberação e permeação cutânea in vitro de nicotina a partir de adesivos transdérmicos. A célula de difusão vertical é considerada um aparato experimental importante em pesquisa e desenvolvimento e pode simular condições in vitro próximas aquelas observadas em ensaios clínicos. Neste trabalho foram avaliados dois dispositivos transdérmicos comercializados no Brasil para liberação controlada de $14 \mathrm{mg}$ de nicotina em um período de 24 horas. Realizaram-se ensaios de liberação, usando membranas de diálise de celulose regenerada, e estudos de permeação cutânea, usando pele de orelha de porcos. Os resultados indicaram que a liberação da nicotina em ambos os dispositivos transdérmicos avaliados seguiu a cinética de Higuchi, enquanto que a permeação cutânea seguiu cinética de ordem zero. As velocidades de liberação foram diferentes para os dispositivos comerciais avaliados, entretanto não foram encontradas diferenças significativas para as velocidades de permeação cutânea. Conforme os estudos de validação, a metodologia mostrou-se apropriada para a avaliação in vitro da liberação e permeação cutânea a partir de adesivos transdérmicos de nicotina. O método proposto foi aplicado em estudos comparativos in vitro entre adesivos transdérmicos comerciais contendo nicotina. Deste modo, o método também pôde ser considerado como ferramenta útil que poderia ser aplicada durante o desenvolvimento de novas formulações transdérmicas para liberação de nicotina.

Unitermos: Nicotina/liberação e permeação cutânea. Adesivos transdérmicos/avaliação. Célula de difusão vertical. Permeação cutânea. Formulações transdérmicas/liberação de nicotina.

\footnotetext{
*Correspondence: G. R. Pereira. Faculdade de Ciências Farmacêuticas, Universidade Federal de Alfenas. Rua Gabriel Monteiro da Silva, 700, 37130-000

- Alfenas - MG, Brasil. E-mail: gislaine.pereira@unifal-mg.edu.br
} 


\section{INTRODUCTION}

The transdermal route appears to have surpassed oral treatment as the most successful innovative research area in drug delivery (Barry, 2001). Numerous drugs have been delivered successfully through transdermal delivery systems (TDS), including scopolamine, nitroglycerin, nicotine, clonidine, fentanyl, estradiol, testosterone, oxybutynin, and, recently, methylphenidate, selegiline, rivastigmine, and rotigotine (Farahmand, Maibach, 2009).

In vitro performance methods that are biologically relevant have been examined to assure the quality of TDS and as a tool in the design of new patches. Ideal conditions for in vitro evaluations of TDS have been those that predict meaningful differences affecting the bioavailability of drugs (Azarmi, Roa, Lobenberg, 2007).

Methods for measuring dissolution/release of a drug from transdermal formulations have been described in important pharmacopeias. However, the dissolution apparatus often requires soaking the sample in an aqueous medium that may interact with polymeric constituents of patches and modify their release characteristics. The conditions in such tests clearly differ markedly from clinical situations when the TDS remains attached to the skin surface, with traditional formulations undergoing changes due to exposure to the atmosphere and skin secretions, and specific excipients may enter into the horny layer, facilitating penetration of active ingredients (Lewis et al., 2007).

Nicotine is considered to be a model molecule for the transdermal route (Barry, 2001). The drug is a tertiary amine that is soluble in water and lipids $\left(\log \mathrm{K}_{\text {ow }}=1.17\right)$ with a molecular weight of 162.23 . The chemical structure of nicotine contains two ionizable groups: a pyridine and a pirrolidone ring with pKa values of 3.04 and 7.84, respectively. It is a colorless to pale yellow liquid that turns brown upon exposure to air (Nair et al., 1997; Pongjanyakul, Suksri, 2010).

In the early 1990s, the FDA approved four different nicotine TDS as adjuvants in smoking cessation. Drug plasmatic levels can be safely assured using these commercial devices for approximately 16 to 24 hours to provide relief of symptoms related to nicotine abstinence (Gore, Chien, 1998).

Various procedures have been recommended in United States Pharmacopeia for the evaluation of nicotine patches, including paddle over disc (Apparatus 5), rotating cylinders (Apparatus 6), and reciprocating holders (Apparatus 7) (United States Pharmacopeia 35, 2012). These pharmacopoeial assays employ a large medium volume without considering the skin barrier. Lewis et al. (1997) evaluated three commercial nicotine TDS using a pharmacopeial apparatus. The amount of drug released was independent of the medium composition and of the apparatus, suggesting a low discriminative power of these methodologies (Lewis et al., 2007). Thus, VDC is considered to be an important experimental apparatus that can simulate conditions closest to those found in clinical trials (Ng et al., 2010).

VDC is a modification of classical Franz diffusion cells. The experimental apparatus has two chambers (donor and receptor) separated by a highly permeable membrane or excised skin. Test formulation is directly applied to the donor chamber and the drug diffuses from the formulation across the support membrane to achieve the receptor phase. Samples can be withdrawn at different times and analyzed using an appropriated instrumental technique (Moser et al., 2001; Hanson, 2010).

In this study, we propose the development and validation of a method for evaluating the release and skin permeation from nicotine patches using VDC. Two different patches available in the Brazilian market were evaluated (rate-controlling membrane and polymeric matrix). Release studies were carried out using regenerated cellulose dialysis membranes and skin permeation studies were carried out across excised porcine ear skin. Nicotine retention in the skin layers was measured after the recommended time of application. Drug quantification was performed using highperformance liquid chromatography-ultraviolet radiation (HPLC-UV). Kinetic studies were carried out to compare the in vitro performance of the evaluated patches.

\section{MATERIAL AND METHODS}

\section{Chemical and reagents}

All reagents used were of analytical grade. Sodium hydroxide, disodium hydrogen phosphate $\left(\mathrm{KH}_{2} \mathrm{PO}_{4}\right)$, sodium dihydrogen phosphate $\left(\mathrm{Na}_{2} \mathrm{HPO}_{4}\right)$, sodium chloride, potassium chloride, phosphoric acid, and triethylamine were purchased from Vetec (Rio de Janeiro, Brazil). (-)-Nicotine ( $\geq 99 \%$, liquid) and (-)-cotinine $(\geq 98 \%)$ were purchased from Sigma-Aldrich (St. Louis, MO, USA). Methanol and acetonitrile for liquid chromatography were acquired from Sigma-Aldrich. HPLC grade water was prepared by Milli-Q reverse osmosis (Millipore, Billerica, MA, USA) and met USP 35 requirements (2012).

\section{Solutions}

The receptor phase (phosphate buffer) was composed of $1.732 \mathrm{~g}$ of $\mathrm{Na}_{2} \mathrm{HPO}_{4}$ and $1.0 \mathrm{~g}$ of $\mathrm{KH}_{2} \mathrm{PO}_{4}$. Salts were 
dissolved in $1000 \mathrm{~mL}$ of water. The isotonic receptor phase was used in skin permeation studies. To prepare the isotonic solution, $8.0 \mathrm{~g}$ of sodium chloride and $0.2 \mathrm{~g}$ of potassium chloride were added for each liter of receptor phase. The $\mathrm{pH}$ of the receptor phase was adjusted to 7.4 with $85 \%$ phosphoric acid or $5 \mathrm{~N}$ sodium hydroxide solution if necessary.

Stock standard solutions of nicotine (1.0 and $10.0 \mathrm{mg} \mathrm{mL}^{-1}$ ) were prepared in methanol.

\section{Nicotine patches}

Two transdermal nicotine patches available in the Brazilian market were purchased from a local drugstore and evaluated in this study, including a rate-controlling membrane device $\left(\mathrm{P} 1,15 \mathrm{~cm}^{2}\right.$ of patch size containing $78 \mathrm{mg}$ of drug) and a polymeric matrix device $\left(\mathrm{P} 2,20 \mathrm{~cm}^{2}\right.$ of patch size containing $35 \mathrm{mg}$ of drug). Both commercial devices claimed to release $14 \mathrm{mg}$ over 24 hours. These patches are indicated for use in the second stage of nicotine replacement therapy.

Patches were cut in order to reduce the surface area so that they could be applied to the donor compartment of the VDC. Devices were cut into circularly shape pieces of equal size (approximately $1.8 \mathrm{~cm}^{2}$, equivalent to the effective diffusion area of VDC). The claimed doses of nicotine released over the 24 hour period in trimmed patches were $1.7 \mathrm{mg} \mathrm{cm}^{-2}$ and $1.3 \mathrm{mg} \mathrm{cm}^{-2}$ for P1 and P2, respectively. The edges of the patches were immediately sealed with impermeable silicone glue to ensure device integrity and prevent lateral nicotine leakage.

\section{Release studies}

In vitro release studies were performed in VDC (Hanson Research Corporation, Chatsworth, CA, USA). Each diffusion cell (effective diffusion area of $1.77 \mathrm{~cm}^{2}$ ) was filled with $7 \mathrm{~mL}$ of the receptor phase previously de-aerated in an ultrasonic bath (Unique, Brazil) for 60 minutes in order to avoid bubble formation. The receptor phase was stirred at a constant speed of $100 \mathrm{rpm}$. Temperature was adjusted to $32 \pm 0.1^{\circ} \mathrm{C}$ using a circulating water bath. Trimmed patches were directly placed over regenerated cellulose dialyses membranes (molecular weight cut-off 12,000 to 14,000 Da, Spectra/ Por $^{\circledR}$, Spectrum Labs, Rancho Dominquez, CA, USA) on the donor chamber. Membranes were previously washed with water in order to remove storage residues. Aliquots (one milliliter) were withdrawn at different time points ( 0 , $3,6,9,12$, and $24 \mathrm{~h}$ ) and were immediately replaced with an equal volume of the receptor phase.

\section{Skin permeation studies}

Skin permeation studies were performed using excised porcine ear skin. Whole skin was excised after slaughter of animals in a local slaughterhouse. Nerves, blood vessels, hairs, and the adipose tissue layer were removed with the aid of a surgical scalpel and scissors. Excised porcine ear skin was frozen and stored at $-6{ }^{\circ} \mathrm{C}$ for up to one month. Excised skin samples without superficial damage were placed on the donor chamber of the VDC (Hanson Research Corporation). Trimmed patches were directly applied to excised skin. Each diffusion cell (effective diffusion area of $1.77 \mathrm{~cm}^{2}$ ) had been filled with $7 \mathrm{~mL}$ of isotonic receptor phase de-aerated in an ultrasonic bath for $60 \mathrm{~min}$. The receptor phase was stirred at a constant speed of $100 \mathrm{rpm}$. Temperature was adjusted to $32 \pm 0.1^{\circ} \mathrm{C}$ using a circulating water bath. Aliquots (one milliliter) were withdrawn at different time points $(0,1$, $3,6,9,12$, and $24 \mathrm{~h}$ ) and were immediately replaced with an equal volume of isotonic receptor phase.

\section{Nicotine extraction from porcine ear skin}

After permeation studies ( $24 \mathrm{~h}$ ), whole skin fragments were removed, briefly washed with water, and placed in polyethylene tubes. Skin homogenates were prepared by triturating whole skin fragments with $10 \mathrm{~mL}$ of receptor phase. Acetonitrile (one milliliter) was added to each sample tube for protein precipitation. Skin homogenates were centrifuged at $1500 \times g$ for 15 minutes and an aliquot of supernatant was withdrawn for nicotine analysis.

\section{Kinetic evaluation of commercial patches}

Results were plotted as the mean cumulative amount of drug released/permeated per unit of surface area against time. Different kinetic models were evaluated:

Zero-order model (concentration against time):

$$
Q_{t}=Q_{0}+K_{0} t
$$

Higuchi's model (concentration against square root of time):

$$
Q_{t} / Q_{0}=K_{H} t^{1 / 2},
$$

First order model (logarithm of the concentration against time):

$$
\log Q_{t}=\log Q_{0}+K_{l} t
$$


where $Q_{t}$ is the amount diffused $(\mathrm{mg})$ at time $t(\mathrm{~h}), Q_{0}$ is the initial amount in the donor compartment $(\mu \mathrm{g}) . K_{0}$ is the zero-order constant $\left(\mu \mathrm{g} \mathrm{h}^{-1}\right), K_{H}$ is the first order constant $\left(\mu \mathrm{g} \mathrm{h}^{-1}\right)$, and $K_{1}$ is the Higuchi's constant $\left(\mu \mathrm{g} \mathrm{h}^{1 / 2}\right)$. The correlation coefficient $(r)$ for each kinetic model was calculated to determine the best fit model.

\section{HPLC analysis}

All samples were analyzed using an auto-sampler HPLC on a Shimadzu (Kyoto, Japan) series LC-10A and a SPD-10AVP dual absorbance detector set at $260 \mathrm{~nm}$ and a SPD-M10AVP diode array detector at 200-370 nm. A Phenomenex (Torrance, CA, USA) C-18 reverse-phase Acqua end-capping $125 \AA, 5 \mu \mathrm{m}$ column $(150 \times 4.6 \mathrm{~mm})$ with a reverse-phase Acqua $5 \mu \mathrm{m}$ guard column $(15 \times 3.2 \mathrm{~mm})$ was used. The mobile phase consisted of phosphate buffer $(20 \mathrm{mM})$ containing $0.2 \%$ of triethylamine: acetonitrile $(8: 2)$. The final $\mathrm{pH}$ was adjusted to 6.9 with phosphoric acid. The flow rate was $1 \mathrm{~mL} \mathrm{~min}^{-1}$. The injection volume was $50 \mu \mathrm{L}$, the run time was $7 \mathrm{~min}$, and the retention time was approximately 4 minutes. All samples were filtered using a $0.45-\mu \mathrm{m}$ syringe filter composed of modified hydrophilic PTFE into silanized HPLC vials prior to injection.

\section{Validation studies}

Validation studies were carried out in order to verify that the method was appropriate for release and skin permeation studies. Validation parameters evaluated included selectivity, linearity and range, accuracy and precision, limit of quantification (LOQ), nicotine recovery from porcine ear skin, and drug stability in receptor phase. Validation studies were performed according to ICH guidelines (2005).

\section{Selectivity}

Selectivity was evaluated by analyzing the receptor phase withdrawn in release and skin permeation studies without nicotine. Standard solutions of nicotine $(150 \mu \mathrm{g}$ $\mathrm{mL}^{-1}$ ) were prepared in the same experimental conditions and analyzed. Peak purity was investigated using spectral analysis with a diode array detector (Shimadzu). Chromatographic separation of nicotine and its major metabolite, cotinine, was also performed.

\section{Linearity/range}

Linearity was assessed using standard solutions prepared for a broad range of concentrations in the receptor phase. Nicotine solutions at concentrations of
$0.5,5,10,50,100,150$, and $300 \mu \mathrm{g} \mathrm{mL}^{-1}$ were analyzed. These studies were performed in triplicate. Linearity was evaluated by linear regression analysis using a weight factor of $1 / x^{2}$. Acceptance criterion was a correlation coefficient of 0.999 or greater and a relative standard deviation (RSD) less than $2.0 \%$ for each concentration level.

\section{Accuracy and precision of analytical procedure}

Solutions were prepared at three concentrations levels $\left(0.5,50\right.$, and $\left.300 \mu \mathrm{g} \mathrm{mL}^{-1}\right)$ and analyzed over three consecutive days. Repeatability (intraday precision) and intermediate precision (interday precision) were determined using the RSD of six preparations. These solutions were also used in order for determining the accuracy of the method. Accuracy was determined as percentage of nicotine observed in receptor phase spiked with known amounts of drug.

\section{Precision of VDC method}

The precision of the VDC method was evaluated during release and permeation studies of Brazilian reference product $(\mathrm{P} 1)$. These studies were performed in triplicate on two different days. Data were analyzed at three time points $(6,12$, and $24 \mathrm{~h})$. Repeatability (intraday precision) and intermediate precision (interday precision) were determined using RSD.

LOQ

LOQ was experimentally established as the lower concentration that showed accuracy and precision during the validation studies.

\section{Drug recovery from skin samples}

Nicotine was recovered from porcine ear skin spiked with known amounts of drug. Aliquots of standard solution of nicotine prepared in acetone $\left(1.0 \mathrm{mg} \mathrm{mL}^{-1}\right)$ were applied to excised skin (approximately $1.8 \mathrm{~cm}^{2}$ ). Three concentration levels $\left(0.1,0.3\right.$, and $\left.0.6 \mathrm{mg} \mathrm{cm}^{-2}\right)$ were spiked in skin samples. These studies were performed in triplicate. Skin samples were placed in polyethylene tubes and allowed to stand for 1 hour to ensure nicotine penetration. Drug extraction was carried out as previously described. Blank solutions of skin homogenates without nicotine were prepared. Standard solutions of nicotine in the receptor phase were prepared to determine the matrix effects from excised porcine ear skin.

\section{Nicotine stability in receptor phase}

Drug stability in receptor phase was evaluated at different time points $(0,24,48,72$, and $96 \mathrm{~h})$. Standard 
solutions of nicotine were protected from direct light exposure. This study was performed in triplicate. All results within $98-102 \%$ of the initial values were considered to have no drug degradation.

\section{Statistical analysis}

Results are expressed as the mean \pm standard deviation (SD). Statistical differences were determined using Student's $t$-test with the level of significance set at $P<0.05$.

\section{RESULTS AND DISCUSSION}

\section{Method validation}

Drug analysis in receptor phase was performed using HPLC-UV to prevent interference from skin contaminants. However, chromatographic analysis of nicotine has been reported to show some analytical limitations (Carlisle, Chicoine, Wygant, 1992; Tambwekar, Kakariya, Garg, 2003). Nicotine is an alkaline drug that can interact with residual silanol groups, leading to secondary retention and increasing the tailing factor. Moreover, nicotine shows hydrophilic characteristics and has a low molecular weight, leading to a reduced retention factor in reversed-phase columns (McCalley, 1999). In this study, we analyzed two strategies described in literature for nicotine analysis by HPLC: the addition of ion pairing reagents and the addition of competitive amines (Carlisle, Chicoine, Wygant, 1992). Sodium dodecyl sulfate was utilized as an ion pair reagent. Some disadvantages were observed in using this strategy. The analyses were more timeconsuming due to column stabilization and the cost of ion pairing reagents for liquid chromatography with appropriated purity grade was high. For these reasons, using competitive amines in the mobile phase is preferable as a rapid, simple, and efficient method for chromatography assays of nicotine. The conditions used were previously described. According to the ICH, system suitability results are considered to be an integral part of validation protocols. The system suitability results are shown in Table I (ICH, 2005).

According to selectivity studies, interfering peaks at the nicotine retention time during the analysis were not observed. Chromatograms of nicotine samples extracted from ear porcine skin and its respective blank are shown in Figure 1.

Peak purity was determined by spectral overlap of the standard solution of nicotine in receptor phase
TABLE I - System suitability results according to USP 35 (2012), $\mathrm{n}=6$

\begin{tabular}{lcc}
\hline Parameters & Mean & SD \\
\hline Retention factor $\left(\mathrm{k}^{\prime}\right)$ & 2.4 & 0.02 \\
Tailing factor & 1.3 & 0.19 \\
Theorical plate number $(\mathrm{N})$ & 3249 & 238 \\
Retention time (min) & 4.3 & 0.02 \\
\hline
\end{tabular}

$\mathrm{SD}$, standard deviation

and nicotine samples extracted from ear porcine skin. A satisfactory similarity index of 0.999217 was found. The purity based on the chromatographic peaks in performance studies using commercial patches was also ensured. Chromatographic separation of nicotine and its major metabolite cotinine was performed at a resolution of 2.5. The retention factor $\left(\mathrm{k}^{\prime}\right)$ for cotinine was 1.9.

A broad linear range was selected to directly measure nicotine in the samples during performance studies, but data heterogeneity must also be evaluated when broad linear ranges are selected. The leak observed for homoscedastic data may have resulted from the large deviations present at large concentrations that generally influence (weight) the regression line more than smaller deviations associated with smaller concentrations. Thus, accuracy at the lower end of the range was impaired. The use of weighted least squares linear regression is a simple and effective method for counteracting this situation (Almeida, 2002).

Homoscedasticity was tested using the F-test (Almeida, 2002). The results indicated a significant difference between variances. Thus, a weighting factor $1 / \mathrm{x}^{2}$ was adopted for the linearity assay. The calibration equation and correlation coefficient ( $\mathrm{r}$ ) were $\mathrm{y}=47854.33 \mathrm{x}+11000.88$ and 0.999769 , respectively. Therefore, drug response was linear at a concentration range of $0.5-300.0 \mu \mathrm{g} \mathrm{mL}^{-1}$.

LOQ was experimentally determined as the lower concentration of range $\left(0.5 \mu \mathrm{g} \mathrm{mL}^{-1}\right)$. The value was established according to the results of accuracy and precision tests and is shown in Table II.

The accuracy and precision results of the analytical method were considered satisfactory and are shown in Table II.

Precision results from in vitro performance studies in VDC are shown in Table III. For these studies, the criteria adopted were an RSD less than $15.0 \%$ due to biological variation in skin permeation studies.

The stability assay demonstrated that nicotine was stable in the receptor phase for 96 hours (Table IV). 


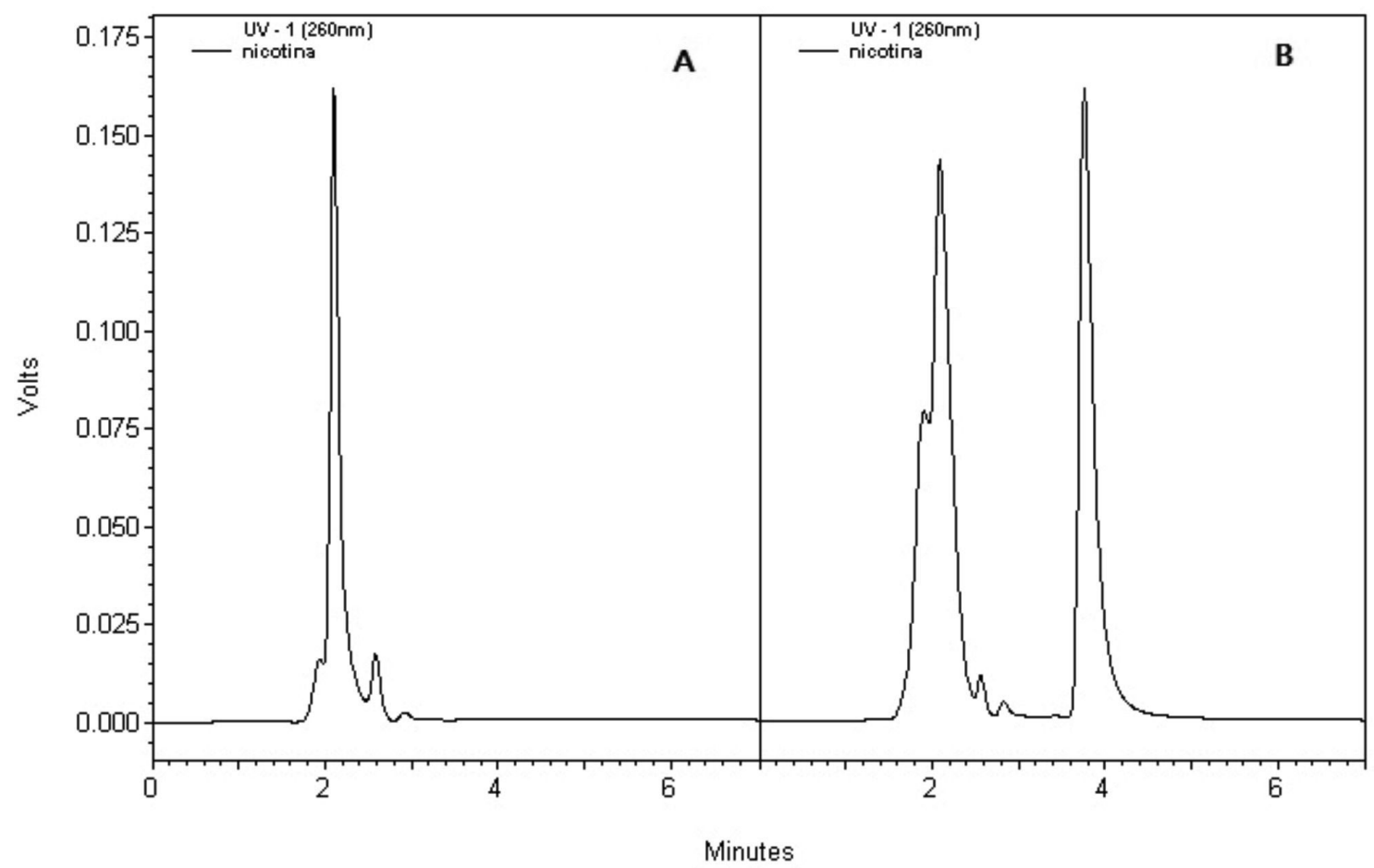

FIGURE 1 - Chromatograms of blank (A) and nicotine (B) extracted from excised skin samples (retention time of nicotine was approximately 4 minutes)

TABLE II - Precision and accuracy of analytical method

\begin{tabular}{lcccc}
\hline \multirow{2}{*}{ Concentration $\left(\mu \mathrm{g} \mathrm{mL}^{-1}\right)$} & \multicolumn{2}{c}{ Precision $(\mathrm{RSD}, \mathrm{n}=6)$} & \multicolumn{2}{c}{ Accuracy $(\%, \mathrm{n}=6)$} \\
\cline { 2 - 5 } & Intraday & Interday & Intraday & Interday \\
\hline 0.5 & 2.7 & 7.9 & 100.5 & 97.0 \\
51.0 & 1.6 & 2.2 & 99.6 & 101.9 \\
306.0 & 2.1 & 1.6 & 100.2 & 100.2 \\
\hline
\end{tabular}

$\mathrm{RSD}$, relative standard deviation

TABLE III - Precision of in vitro performance studies

\begin{tabular}{lllll}
\hline \multirow{2}{*}{ Time $(\mathrm{h})$} & \multicolumn{2}{l}{ Precision of release studies $(\mathrm{RSD}, \mathrm{n}=6)$} & \multicolumn{2}{l}{ Precision of skin permeation studies $(\mathrm{RSD}, \mathrm{n}=6)$} \\
\cline { 2 - 5 } & Intraday & Interday & Intraday & Interday \\
\hline 6 & 0.3 & 9.1 & 3.5 & 8.7 \\
12 & 10.3 & 9.5 & 2.8 & 3.5 \\
24 & 9.6 & 11.3 & 2.8 & 2.3 \\
\hline
\end{tabular}

RSD, relative standard deviation

Measuring stability is important for ensuring that no drug degradation has occurred during in vitro assays prior to HPLC analysis.

Recoveries of known amounts of nicotine from skin were performed (Table V). The results demonstrated that high percentages of nicotine can be recovered from skin samples.

\section{Evaluation of nicotine patches}

In vitro performance studies are an important tool for characterizing nicotine patches. Release studies can ensure batch-to-batch consistency and detect manufacturing deviations during routine quality control. Skin permeation studies are important in research and development for 
TABLE IV - Stability of nicotine in receptor phase $(\mathrm{n}=3)$

\begin{tabular}{lccccc}
\hline & $\begin{array}{c}\text { Initial } \\
\text { solution }\end{array}$ & $24 \mathrm{~h}$ & $48 \mathrm{~h}$ & $72 \mathrm{~h}$ & $96 \mathrm{~h}$ \\
\hline Mean \% & 100.00 & 100.65 & 100.58 & 101.55 & 101.56 \\
RSD & 1.69 & 1.68 & 1.76 & 1.48 & 1.47 \\
\hline
\end{tabular}

RSD, relative standard deviation

TABLE V - Recovery of nicotine from skin samples $(n=3)$

\begin{tabular}{cc}
\hline Concentration $\left(\mathrm{mg} \mathrm{cm}^{-2}\right)$ & Recovery $(\%, \mathrm{n}=3) \pm \mathrm{RSD}$ \\
\hline 0.1 & $95.6 \pm 1.8$ \\
0.3 & $97.7 \pm 0.2$ \\
0.6 & $97.3 \pm 0.1$ \\
\hline
\end{tabular}

RSD, relative standard deviation

predicting in vivo behavior of transdermal and topic formulations with respect to the skin barrier (Olivier, Rabouan, Couet, 2003; Azarmi, Roa, Lobenberg, 2007). In general, differences are expected between release and permeation rates. In this study, release and permeation studies were conducted using VDC and results were used to compare the in vitro performance of commercial devices.

In vitro release profiles of two different patches are presented in Figure 2. After 24 hours, the amount of nicotine released from P1 and P2 were $846.3 \pm 11.3 \mu \mathrm{g}$ $\mathrm{cm}^{-2}$ and $1033.3 \pm 97.7 \mu \mathrm{g} \mathrm{cm}^{-2}$, respectively; these values were significantly different $(P<0.05)$. Regarding the percentage of claimed drug release, $\mathrm{P} 2$ released $145.4 \%$ at 24 hours while P1 released $90.7 \%$ at this same time. Due to the different design of the patches, the largest amounts released by $\mathrm{P} 2$ were associated with polymeric matrix dissolution. Despite the use of a dialysis membrane to

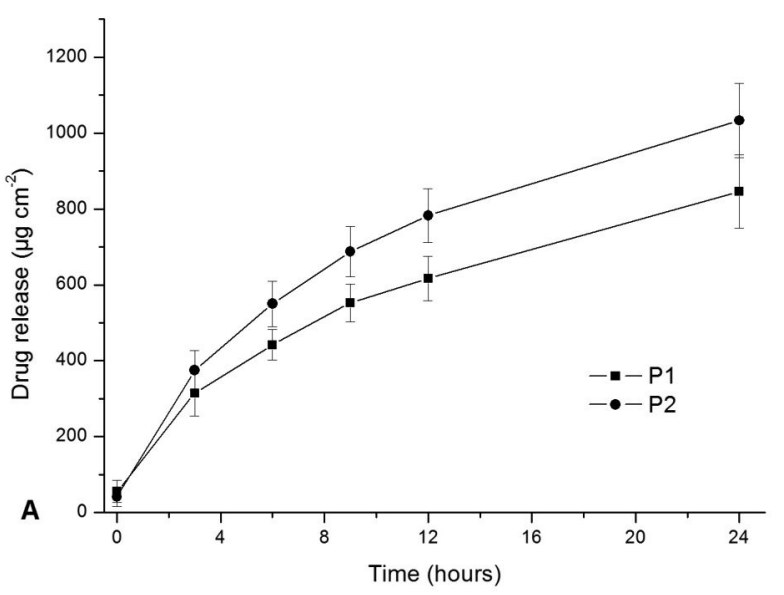

decrease direct contact between the patch and the receptor phase, the aqueous medium remained highly permeable through the dialysis membrane and its contact with patch matrix increased. In P1, the rate-controlling membrane from the formulation prevented device dissolution; consequently, released amounts were low compared to the claimed release amount.

For any TDS, the initial concentration gradient between the drug reservoir and skin should be sufficiently high to ensure the required drug flux over the recommended time of application. These considerations imply that the amount of drug in the patches is generally much larger than the amount of released drug (Lewis et al., 1997; Barry, 2001). P2 contains a low drug load compared to $\mathrm{P} 1$. According to our release studies, $\mathrm{P} 2$ released $58.1 \%$ of its total nicotine load at 24 hours, while P1 released only $16.3 \%$ of its total nicotine load by the same time point.

The results of permeation studies are presented in Figure 3. After 24 hours, the permeated amounts from P1 and P2 were $992.5 \pm 22.4 \mu \mathrm{g} \mathrm{cm}^{-2}$ and $892.9 \pm 96.0 \mu \mathrm{g} \mathrm{cm}^{-2}$, respectively. Results were significantly different $(P<0.05)$ despite their similar values. Permeation amounts were closer or slightly higher than the claimed release dose. The results were $106.3 \%$ and $127.6 \%$ for $\mathrm{P} 1$ and $\mathrm{P} 2$, respectively.

The most relevant animal model for human skin is the pig. Porcine skin has histological and biochemical properties that have repeatedly been shown to be similar to human skin. Porcine ear skin is particularly well-suited for permeation studies and gives comparable results to human skin. However, porcine ear skin was shown to be more permeable than human skin in some cases (Godin, Touitou, 2007). Thus, extrapolation of the results must be carefully performed.

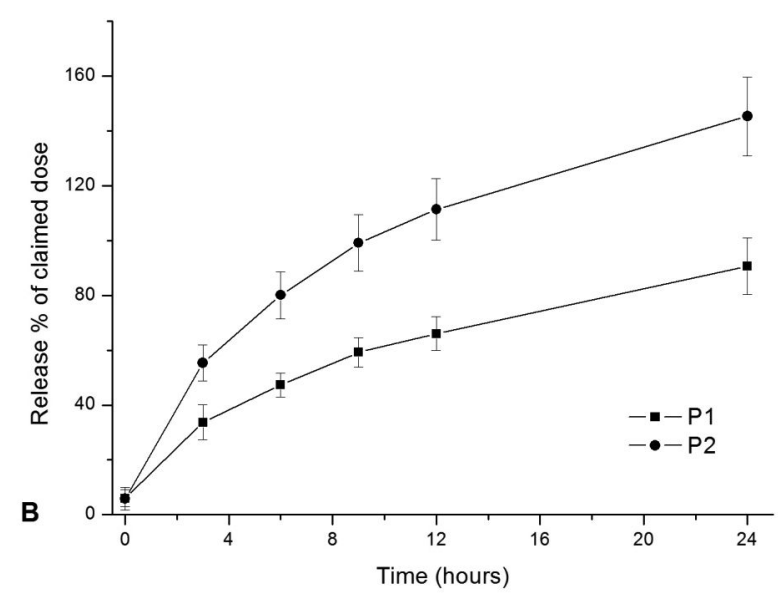

FIGURE 2 - Release profiles from nicotine commercial patches P1 ( $\bullet$ ) and P2 (•) using the VDC method, n = 6. Results are expressed as the cumulative amount of drug released (A) and the cumulative \% of dose released (B). 

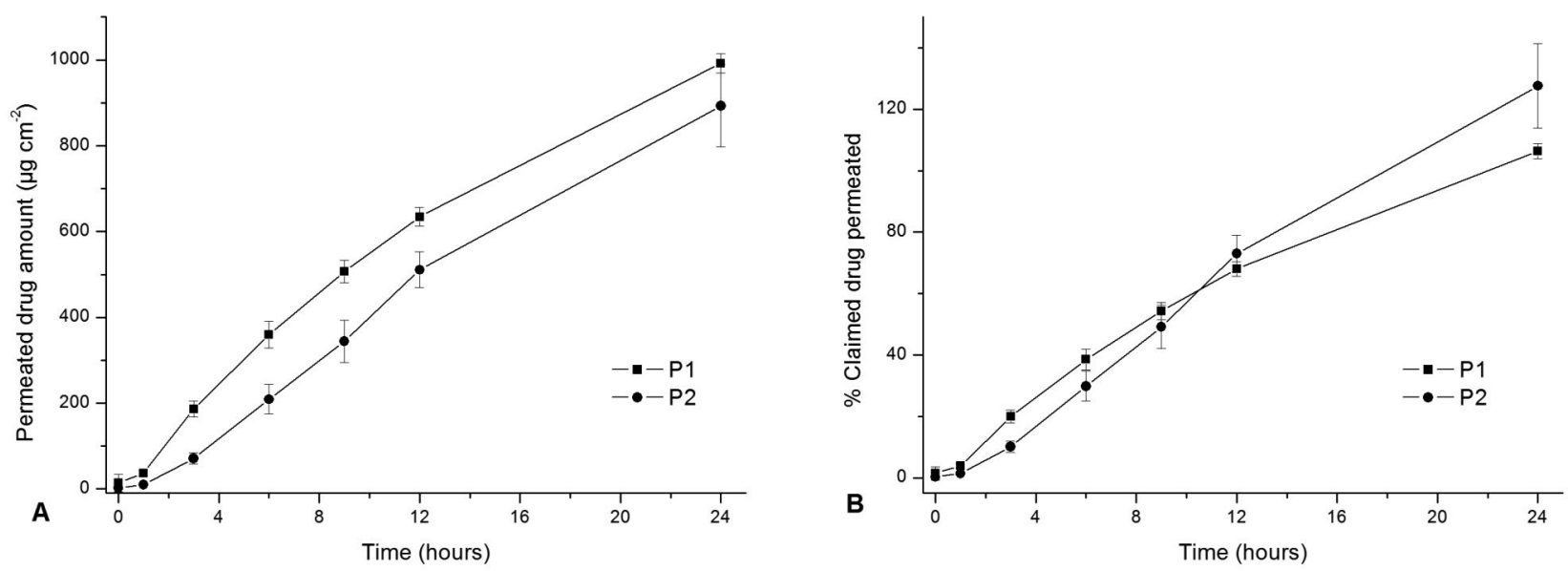

FIGURE 3 - In vitro skin permeation profiles from commercial nicotine patches P1 ( $\bullet$ ) and P2 (•) using the VDC method, $\mathrm{n}=6$. Results are expressed as cumulative amount of drug that permeated through the skin (A) and the cumulative $\%$ of dose permeated (B).

According to Kalia and Guy (2001), the property of a patch to control drug release can be measured using the fractional rate control (Fd). Fd is the ratio between the amount of drug permeating through the skin barrier and the amount of drug released from the TDS into an aqueous sink system. Thus, an $\mathrm{Fd}=1$ implies that delivery is controlled entirely by the device; however, when $\mathrm{Fd}<1$, the skin is also contributing to the controlled release. Results for Fd were 1.17 and 0.88 for $\mathrm{P} 1$ and $\mathrm{P} 2$, respectively.

Nicotine is a highly permeable drug and the total drug amount delivered must be rapidly permeated across the skin. Thus, it can be expected that the skin barrier has a limited influence on drug permeation rate. For patch $\mathrm{P} 2$, the amount of drug permeated was low compared to the amount of drug released. This suggests that the contact between the formulation and the receptor phase decreased at the skin barrier, leading to minor swelling of the polymeric matrix in permeation studies. In this manner, $\mathrm{Fd}$ indicates that approximately $88 \%$ of the release rate of P2 was controlled by formulation. Compared to P1, the amount of drug permeated was higher than the amount of drug released, giving an $\mathrm{Fd}$ value of greater than 1 . These results suggest that the rate-controlling membrane patch regulates the release rate throughout its extension, while the skin has a minor effect in total drug flux. It is important to note that the value of Fd evaluates only the amounts of drug released and permeated in a given period of time and it must be considered that the skin barrier has a significant effect on release kinetic.

The effect of trimming the edges of the nicotine patch before application in the Franz-type cell has been discussed in previous studies (Lewis et al., 1997; Olivier, Rabouan, Couet, 2003). Lateral diffusion of nicotine can occur in the device edges that are not in contact with the effective area of diffusion. This can lead to an overestimation of the results. According to Olivier and et al. (2003), reducing the surface area of the device leads to a reduction of the cumulative amounts of drug permeated through the skin and, consequently, decreased permeation rates (Olivier, Rabouan, Couet, 2003). In this study, we trimmed nicotine patch to a size as close as possible to the effective diffusion area in order to prevent lateral diffusion of the drug/formulation and to assure patch integrity.

\section{Nicotine retention in the skin}

Nicotine can be retained in the skin despite its high permeability. At steady state, the concentration of nicotine in the skin layers is expected to be maintained in a stationary state. The results of nicotine retained within skin layers are presented in Table VI.

TABLE VI - Amounts of nicotine retained within skin after $24 \mathrm{~h}$ of skin permeation studies, $\mathrm{n}=6$

\begin{tabular}{cc}
\hline Evaluated patch & Concentration $\pm \mathrm{SD}\left(\mathrm{mg} \mathrm{cm}^{-2}\right)$ \\
\hline P1 & $0.362 \pm 0.038$ \\
P2 & $0.320 \pm 0.029$ \\
\hline
\end{tabular}

$\mathrm{SD}$, standard deviation

The retained amounts did not significantly differ between the two commercial patches $(P=0.055)$. These results indicate that the difference between release/ permeation was not related to drug retention within skin. Furthermore, it is important to note that drug retention was due to the possibility of accumulation of nicotine within 
TABLE VII - Correlation coefficients determined for evaluated kinetic models

\begin{tabular}{cccccccc}
\hline & \multirow{2}{*}{ Patch } & Nicotine dose & \multicolumn{3}{c}{ Release kinetics } & \multicolumn{3}{c}{ Permeation kinetics } \\
\cline { 3 - 7 } & $\left(\mathrm{mg} \mathrm{cm}^{-2}\right)$ & \multicolumn{3}{c}{ Correlation coefficient $(\mathrm{r})$} & \multicolumn{3}{c}{ Correlation coefficient $(\mathrm{r})$} \\
\cline { 3 - 7 } & & Zero-order & First order & Higuchi's model & Zero-order & First order & Higuchi's model \\
\hline P1 & 5.20 & 0.93399 & 0.74901 & 0.99488 & 0.98252 & 0.75991 & 0.97722 \\
P2 & 1.75 & 0.92589 & 0.72035 & 0.99387 & 0.99287 & 0.79590 & 0.94440 \\
\hline
\end{tabular}

skin layers, resulting in the release of residual amounts of nicotine after removing the patches (Benowitz, Hukannen, Jacob III, 2009).

\section{Kinetic studies}

Kinetic evaluations were carried out using data obtained in the performance studies. Results are presented in Table VII.

Both devices showed Higuchi's release kinetics during release studies. P1 showed a nicotine flux of 163.6 $\pm 13.4 \mu \mathrm{g} \mathrm{cm}^{-2} \mathrm{~h}^{-1 / 2}$, whereas the release of P2 showed a greater drug flux of $207.1 \pm 42.2 \mu \mathrm{g} \mathrm{cm}^{-2} \mathrm{~h}^{-1 / 2}$. These values were significantly different $(P<0.05)$.

Zero-order or Higuchi's release profiles can be expected for TDS with rate-controlling membranes, as was observed for P1. In this design, the drug remains stored in a reservoir that is enclosed on one side with an impermeable backing. These patches also contain an adhesive layer that avoids direct contact between the semipermeable membrane and the horny layer. In this case, zero-order kinetics can be expected. However, nicotine can accumulate in the adhesive layer during storage, leading to a Higuchi's release profile in practice. For TDS with a polymeric matrix, such as for P2, drug is dispersed into a polymeric material, simplifying the manufacturing process. Matrix systems may have only three layers without a semi-permeable membrane or just two layers by incorporating the drug directly into a polymeric adhesive matrix. Matrix release profiles are expressed as Higuchi's model, which is characterized by passive diffusion from the polymeric matrix (Gore, Chien, 1998).

Although the release profile for both patches fit better to Higuchi's model, data obtained from permeation studies showed a better fit to the zero-order model (linear versus time). Permeation rates of P1 and P2 were $41.7 \pm$ $1.2 \mu \mathrm{g} \mathrm{cm}^{-2} \mathrm{~h}^{-1}$ and $38.3 \pm 3.6 \mu \mathrm{g} \mathrm{cm}^{-2} \mathrm{~h}^{-1}$, respectively. The results were not significantly different $(P=0.068)$. This demonstrates that permeated amounts of $\mathrm{P} 1$ were larger than the values of the amounts of drug released $(\mathrm{Fd}>1)$, with the skin having an important effect on drug kinetics.

\section{CONCLUSION}

The VDC method was validated and applied to characterize the release and permeation kinetics from nicotine TDS. We demonstrated that in vitro performance of commercial devices with different designs (ratecontrolling membrane or polymeric matrix) can be evaluated using VDC. The release rate of nicotine from TDS was influenced by the formulation and the skin barrier. Both devices showed release profiles following Higuchi release kinetics and permeation profiles following the zero-order model, likely due to skin barrier. This method showed appropriate results for kinetic evaluations of nicotine patches; however, predicted plasma concentrations in humans is necessary for establishing an in vivo-in vitro correlation. Although the VDC method generally simulates in vivo conditions, it should be carefully evaluated whether the amounts determined in vitro are associated with the amounts released by the device during in vivo clinical trials. Thus, this method was found to be appropriate for comparative studies between different transdermal nicotine patches and may be a useful tool for designing new transdermal nicotine delivery systems.

\section{ACKNOWLEDGEMENTS}

The authors are grateful to FAPEMIG (Minas Gerais, Brazil), CAPES (Brasília, Brazil) and UNIFAL/ MG (Minas Gerais, Brazil) for research fellowships.

\section{REFERENCES}

ALMEIDA, A.M. Linear regression for calibration lines revisited: weighting schemes for bioanalytical methods. $J$. Chromatogr. B, v.774, n.2, p.215-222, 2002.

AZARMI, S.; ROA, W.; LOBENBERG, R. Current perspectives in dissolution testing of conventional and novel dosages forms. Int. J. Pharm., v.328, n.1, p.12-21, 2007. 
BARRY, B. Novel mechanisms and devices to enable successful transdermal drug delivery. Eur. J. Pharm. Sci., v.14, n.2, p.101-114, 2001.

BENOWITZ, N.L.; HUKANNEN, J.; JACOB III; P. Nicotine chemistry, metabolism, kinetics and biomarkers. Handb. Exp. Pharmacol., v.192, n.1, p.29-60, 2009.

CARLISLE, M.R.; CHICOINE, M.L.; WYGANT, M.B. A stability-indicating high performance liquid chromatography assay for nicotine in transdermal patches. Int. J. Pharm., v.80, n.1-3, p.227-242, 1992.

FARAHMAND, S.; MAIBACH, H.I. Transdermal drug pharmacokinetics in man: Interindividual variability and partial prediction. Int. J. Pharm., v.367, n.1-2, p.1-15, 2009.

GODIN, B.; TOUITOU, E. Transdermal skin delivery: prediction for humans from in vivo, ex vivo and animal models. Adv. Drug Deliv. Rev., v.59, n.11, p.1152-1161, 2007.

GORE, A.V.; CHIEN, Y.W. The nicotine transdermal system. Clin. Dermatol., v.16, n.5, p.599-615, 1998.

HANSON, R. A primer on release-rate testing of semisolids. Dissolut. Technol., v.17, n.4, p.33-35, 2010.

\section{INTERNATIONAL CONFERENCE ON HARMONISATION} OF TECHNICAL REQUIREMENTS FOR REGISTRATION OF PHARMACEUTICALS FOR HUMAN USE. Publications: guidelines. "Quality" topics. Q2 (r1) validation of analytical procedures: text and methodology. Geneva: ICH, 2005. 13 p.

LEWIS, D.; PAULO, M.; FAUSTINO, E.; FARINHA, A. In vitro comparative studies of transdermal nicotine delivery systems. Int. J. Pharm., v.148, n.2, p.177-189, 1997.
MCCALLEY, D.V. Comparison of the performance of conventional C18 phases with others of alternative functionality for the analysis of basic compounds by reversed-phase high-performance liquid chromatography. J. Chromatogr. A, v.844, n.1-2, p.23-38, 1999.

MOSER, K.; KRIWET, K.; NAIK, A.; KALIA, Y.N.; GUY, R.H. Passive skin penetration enhancement and its quantification in vitro. Eur. J. Pharm. Biopharm., v.52, n.2, p.103-112, 2001.

NAIR, M.K.; CHETTY, D.J.; HO, H.; CHIEN, Y.W. Biomembrane permeation of nicotine: Mechanistic studies with porcine mucosae and skin. J. Pharm. Sci., v.86, n.2, p.257-262, 1997.

NG, S.F.; ROUSE J.J.; SANDERSON F.D.; MEIDAN, V.; ECCLESTON G.M. Validation of a static Franz diffusion cell system for in vitro permeation studies. AAPS PharmSciTech., v.11, n.3, p.1432-1441, 2010.

OLIVIER, J.C.; RABOUAN, S.; COUET, W. In vitro comparative studies of two marketed transdermal nicotine delivery systems: Nicopatch $\AA$ and Nicorette ${ }^{\circledR}$. Int. J. Pharm., v.252, n.1-2, p.133-140, 2003.

PONGJANYAKUL, T.; SUKSRI, H. Nicotine-loaded sodium alginate -magnesium aluminum silicate (SA-MAS) films: Importance of SA - MAS ratio. Carbohydr. Polym., v.80, n.4, p.1018-1027, 2010.

TAMBWEKAR, K.R.; KAKARIYA, R.B.; GARG, S. A validated high performance liquid chromatographic method for analysis of nicotine in pure form and from formulations. J. Pharm. Biomed., v.32, n.3, p.441-450, 2003.

UNITED STATES PHARMACOPEIA. 35.ed. National formulary 30. Rockville: United States Pharmacopeia Convention, 2012. $5089 \mathrm{p}$.

Received for publication on $12^{\text {th }}$ November 2012 Accepted for publication on $06^{\text {th }}$ June 2013 